\title{
Nitrogen Fertilization of the Host Plant Influences Production and Pathogenicity of Botrytis cinerea Secondary Inoculum
}

\author{
Manzoor Ali Abro, François Lecompte, Florian Bryone, and Philippe C. Nicot
}

First, third, and fourth authors: INRA, UR407 Pathologie végétale, Domaine Saint Maurice, CS 60094, F-84143 Montfavet cedex, France; and second author: INRA, UR 1115 Plantes et systèmes de cultures horticoles, Domaine Saint Paul, CS 40509, F-84914, Avignon cedex, France.

Accepted for publication 1 November 2012.

\begin{abstract}
Abro, M. A., Lecompte, F., Bryone, F., and Nicot, P. C. 2013. Nitrogen fertilization of the host plant influences production and pathogenicity of Botrytis cinerea secondary inoculum. Phytopathology 103:261-267.

The influence of nitrogen $(\mathrm{N})$ nutrition on a plant's susceptibility to Botrytis spp. and other pathogens is well documented. However, little is known of possible effects on sporulation of the pathogen on diseased tissue and on the pathogenicity of resulting secondary inoculum. To address this question, sporulation by two strains of Botrytis cinerea was quantified on tomato plants produced under different $\mathrm{N}$ irrigation regimes

at 15 to $30 \mathrm{mM}$. The secondary inoculum was collected and used to inoculate pruning wounds on tomato plants produced under a standard fertilization regime. Pathogenicity of the spores was significantly influenced by the nutritional status of their production substrate. Disease severity was highest with spores produced on plants with very low or very high $\mathrm{N}$ fertilization $\left(\mathrm{NO}_{3}{ }^{-}\right.$at 0.5 or $\left.30 \mathrm{mM}\right)$. It was lowest for inoculum from plants with moderate levels of $\mathrm{N}$ fertilization. These results suggest that it may be possible to find an optimum level of $\mathrm{N}$ fertilization to reduce the production of secondary inoculum and its pathogenicity to tomato.
\end{abstract} with inputs of $\mathrm{NO}_{3}^{-}$at 0.5 to $45 \mathrm{mmol} \operatorname{liter}^{-1}(\mathrm{mM})$. Sporulation decreased significantly $(P<0.05)$ with increasing $\mathrm{N}$ fertilization up to $\mathrm{NO}_{3}$
Additional keywords: gray mold, Solanum lycopersicum.
Sporulation is essential for the reproduction and spread of many fungi. For those that are airborne plant pathogens, the kinetics and abundance of spore production play a key role in the development of epidemics $(10,33)$. Fungal sporulation can be influenced by many factors, including the availability of nutrients $(7,15,34,60)$. Some fungi have specific carbon (C) and nitrogen (N) requirements whereas, for others, sporulation is triggered by nutrient depletion $(9,12)$. For most fungi, the specific substrate also influences spore production. Much information has been generated to optimize substrate composition for mass producing fungi of industrial interest such as biocontrol agents against plant pathogens $(17,50)$ and insects $(19,24,26,44)$. The effects of culture conditions and host substrate on initial spore production have also been documented for certain plant-pathogenic fungi $(21,32$, 35,42 ). Surprisingly little information is available on possible effects of plant fertilization on subsequent sporulation of pathogens, although it is known to modify the concentration of nutrients available to plant pathogens and to affect plant susceptibility (23).

The composition and type of nutrient substrate has also been shown to affect the pathogenicity of spores produced in vitro by plant-pathogenic Colletotrichum truncate, Fusarium avenaceum, and Phytophthora infestans $(43,54,58)$; and the entomopathogen Beauveria bassiana (4). Aggressiveness may be attenuated when spores are produced under conditions of nutrient stress, as exemplified by Bipolaris sorokiniana conidia (2), or increased with increasing availability of key nutrients such as glucose, as exemplified by Botrytis cinerea (38). However, to our knowledge,

Corresponding author: P. C. Nicot; E-mail address: philippe.nicot@avignon.inra.fr

* The $\boldsymbol{e}$-Xtra logo stands for "electronic extra" and indicates that the online version contains two supplemental tables. Figure 2 appears in color online.

http://dx.doi.org/10.1094/PHYTO-08-12-0189-R

(c) 2013 The American Phytopathological Society no information is available on effects of plant fertilization on the pathogenicity of fungal spores produced on diseased tissues.

$B$. cinerea, the causal agent of gray mold, is responsible for severe losses in many crops, including tomato $(36,45,53)$. In favorable conditions, this fungus can produce a large quantity of spores on diseased tissue (35) that are easily dispersed and have a key role in the development of gray mold epidemics (8). The control of gray mold is highly dependent on fungicide applications, and much research is dedicated to developing alternative control methods (13). A possible alternative could consist of reducing sporulation with the help of biocontrol agents (27) or the use of UV-filtering films (35). Another possibility to reduce sporulation might be through the manipulation of plant fertilization. Several studies have shown that high $\mathrm{N}$ nutrition of the host plant promotes the sporulation of several fungi, including $B$. cinerea on sweet basil (55). Although no information is available for the sporulation of $B$. cinerea on tomato, previous studies have shown that high $\mathrm{N}$ nutrition reduces the susceptibility of the plant $(22,31,52)$. Furthermore, we were unable to find information regarding the effect of $\mathrm{N}$ fertilization of plants on the pathogenicity of resulting secondary inoculum of $B$. cinerea.

The objectives of this study were to (i) assess the effects of $\mathrm{N}$ nutrition of tomato on sporulation of $B$. cinerea on diseased tissue and on pathogenicity of the resulting secondary inoculum and (ii) to correlate these effects with modifications in plant tissue composition.

\section{MATERIALS AND METHODS}

Production of plants under different $\mathbf{N}$ fertilization regimes. Tomato plants (Solanum lycopersicum var. esculentum 'Swanson') were grown from seed in $1-\mathrm{cm}^{3}$ rock wool cubes in a heated greenhouse and transferred 10 days after sowing to rock wool blocks as previously described (33). The plants were irrigated with a standard commercial greenhouse nutrient solution the first 
month and then transplanted to 2-liter pots filled with a mixture $(1: 1, \mathrm{vol} / \mathrm{vol})$ of vermiculite and pozzolana (inert crushed volcanic rock) to start the different $\mathrm{N}$ fertilization treatments (40 plants per $\mathrm{N}$ level). Five levels of nitrate concentrations $(0.5,5,15,30$, and $\left.45 \mathrm{mmol} \mathrm{liter}^{-1}[\mathrm{mM}]\right)$ were evaluated to span a wide range from severe $\mathrm{N}$ deficiency to heavy excess. To minimize possible complex nutritional effects on the physiology of the plants, two constraints were taken into account when designing the chemical composition of the nutrient solutions: (i) keep other elements (particularly phosphorus $[\mathrm{P}]$, potassium $[\mathrm{K}]$, calcium $[\mathrm{Ca}]$, and magnesium $[\mathrm{Mg}]$ at a constant concentration in the different $\mathrm{N}$ treatments, because they may also influence plant susceptibility to pathogens (23), and (ii) keep the total electrical conductivity similar in all treatments, because this is known to influence the physiology of tomato (28). The composition of the 15-mM nitrate solution was adapted from nutrient solutions used by growers in commercial tomato glasshouses. It contained three types of nitrate salts $\left(\mathrm{KNO}_{3}, 10 \mathrm{mM} ; \mathrm{Ca}\left(\mathrm{NO}_{3}\right)_{2}, 1.75 \mathrm{mM}\right.$; and $\left.\mathrm{NH}_{4} \mathrm{NO}_{3}, 1.5 \mathrm{mM}\right)$. Thus, the total $\mathrm{N}$ level of that solution amounted to $15 \mathrm{mM}$ as nitrate plus $1.5 \mathrm{mM}$ as ammonium. For solutions with lower $\mathrm{N}$ concentrations, no ammonium was used and $\mathrm{Cl}^{-}$salts (a combination of $\mathrm{KCl}, \mathrm{CaCl}_{2}$, and $\mathrm{NaCl}$ ) were substituted to nitrate in order to maintain similar cation concentrations. Designing solutions with higher $\mathrm{N}$ levels within the two above-mentioned constraints was more complex. To achieve higher $\mathrm{N}$ concentrations with minimal consequences for the electrical conductivity, $\mathrm{NH}_{4} \mathrm{NO}_{3}$ was added to the solutions, bringing the total $\mathrm{N}$ levels to 46.5 and $76.5 \mathrm{mM}$ (including 16.5 and $31.5 \mathrm{mM}$ as ammonium) for the solutions containing 30 and $45 \mathrm{mM}$ of nitrate, respectively. To maintain the electric conductivity at the same level as in other $\mathrm{N}$ treatments, the addition of $\mathrm{NH}_{4} \mathrm{NO}_{3}$ was fully compensated for by the removal of $\mathrm{NaCl}$ in the solution with $30 \mathrm{mM}$ nitrate. This was not sufficient for the highest $\mathrm{N}$ level. Thus, this last solution had a higher electric charge $(59.5 \mathrm{meq}$ of anions and $61.5 \mathrm{meq}$ of cations) than the four others (44.5 meq of anions and 46.5 meq of cations). Phosphorous (P, $2 \mathrm{mM}), \mathrm{K}(12 \mathrm{mM}), \mathrm{Ca}(5 \mathrm{mM}), \mathrm{Mg}$ $(4 \mathrm{mM})$, and minor elements were kept constant in all solutions.

The plants were fertigated with a drip-irrigation system (one dripper per pot with 1-min pulses) several times a day depending on the climatic demand. Three pots chosen at random were weighed continuously to evaluate water loss as an indicator of climatic demand. The $\mathrm{pH}$ was adjusted to 6 in each treatment by the addition of $\mathrm{H}_{2} \mathrm{SO}_{4}$. Plants were grown on the respective solutions for 4 weeks prior to use for experiments on spore production and pathogenicity of secondary inoculum of $B$. cinerea.

Tissue content assessment. Just before inoculation, five plants were randomly selected from each $\mathrm{N}$ regime. For each plant, the stem and leaves were weighed separately and then dried for $72 \mathrm{~h}$ at $70^{\circ} \mathrm{C}$. The tissue content was then analyzed for $\mathrm{Ca}, \mathrm{C}, \mathrm{Mg}$, nitrate, $\mathrm{K}, \mathrm{P}$, and total $\mathrm{N}$ and expressed as milligrams per gram of dry matter as described previously (31). Soluble sugars (glucose, fructose, and sucrose) were determined with an enzymatic method in a microplate reader as proposed by Gomez et al. (18).

Evaluation of spore production by $\boldsymbol{B}$. cinerea on differentially fertilized plants. Strains and preparation of primary inoculum. For the spore production assay, two strains of $B$. cinerea (BC1 and $\mathrm{BC} 21)$ were used. They were shown in earlier work to differ in their level of aggressiveness on tomato (31). Primary inoculum for both strains was produced in petri dishes on potato dextrose agar (PDA) incubated at $21^{\circ} \mathrm{C}$ under cool white fluorescent light (14-h photoperiod; $114 \mu \mathrm{mol} \mathrm{m}^{-2} \mathrm{~s}^{-1}$ ). After 3 days of culture, mycelial plugs were excised from the growing margin of the colony with a cork borer and used to inoculate detached organs prepared from the plants grown under the different $\mathrm{N}$ fertilization treatments.

Preparation and inoculation of detached plant organs. The plants were severed at the base and 2-cm-long segments were excised from the stems and petioles (three each per plant). Leaf discs ( $2 \mathrm{~cm}$ in diameter) were excised from the leaves (three discs per plant, one from each of leaf number 3, 4, and 5, starting from the collar upward). Each sample was weighed (milligrams fresh weight) and then placed individually in the 3-cm-diameter cap of a screw-cap tube. Each stem and petiole segment was inoculated in the center with a 5-mm-diameter mycelial plug and each leaf disk with a 2-mm-diameter plug, ensuring that the mycelium was in contact with plant tissue. The caps were placed in transparent polystyrene boxes over moistened filter paper, covered with lids, and placed in a growth chamber under cool white fluorescent light (16-h photoperiod; $162 \mu \mathrm{mol} \mathrm{m} \mathrm{m}^{-2} \mathrm{~s}^{-1}$ ) at $20^{\circ} \mathrm{C}$. For each strain of B. cinerea, nine replicate samples of each type of plant organ were inoculated (three per plant $\times$ three plants) and the sporulation experiment was repeated twice.

Quantification of spore production on detached organs. Ten days after inoculation, the samples were removed from the growth chamber and $5 \mathrm{ml}$ of an alcoholic solution (containing 20\% ethanol [vol/vol] and $100 \mu \mathrm{l}$ of Tween 80 per liter) were added to each cap. A centrifuge tube was then screwed onto each cap and the samples were stored at $4{ }^{\circ} \mathrm{C}$ until spore counting. Two liquid subsamples were taken from each tube and spores were counted with a Malassez hemocytometer. Spore production on each detached organ was then expressed as number of spores per gram of fresh weight.

Assessment of pathogenicity of secondary inoculum. Production of secondary inoculum. Leaf disks and stem segments excised from plants produced under four different $\mathrm{N}$ levels $(0.5,5$, 15 , and $30 \mathrm{mM}$ nitrate) were inoculated and incubated as described above. Ten days after inoculation, dry spores were collected from the different organs into Eppendorf tubes using a microaspirator connected to a vacuum pump in order to recover spores without plant debris or fluids from macerated tissue. The dry spores were stored at $4{ }^{\circ} \mathrm{C}$ until use for inoculation trials $(4$ days maximum). Immediately before plant inoculation, water suspensions were prepared from these dry spores. All inocula were filtered through $30-\mu \mathrm{m}$ mesh sterile filters (to remove possible mycelial fragments) and adjusted to a concentration of $10^{6}$ spores $\mathrm{ml}^{-1}$. Two such batches of secondary inoculum were produced independently to assess their pathogenicity. Spores from 14-day-old cultures of both strains of $B$. cinerea on PDA were used as a reference (31).

Production of plants under a standard fertilization regime. The pathogenicity of secondary inoculum was tested on two independent batches of tomato plants (Monalbo) produced under a single $\mathrm{N}$ regime. The plants were grown in 9-by-9-by-8-cm disposable pots containing $450 \mathrm{ml}(120 \mathrm{~g})$ of a commercial potting mixture (SP533; Klasmann-Deilmann, Germany) composed of blended white and black sphagnum peat (containing 14-16-18 $\mathrm{N}-\mathrm{P}-\mathrm{K}$ fertilizer at $5.25 \mathrm{~g} / \mathrm{kg}$ ). The plants were watered daily according to their needs with a solution containing $0.8 \%$ ( $\mathrm{vol} / \mathrm{vol}$ ) of a standard nutrient solution prepared by mixing $48 \mathrm{~g}$ of $16-8-18$ N-P-K fertilizer (EDDHA Optiplan, Duclos, France) per liter of water. They were inoculated after 9 weeks of growth, when they had approximately nine fully expanded leaves.

Inoculation with secondary inoculum. Four plants were used for each type of inoculum and each plant was inoculated with both strains of $B$. cinerea. Four leaves were removed on each plant, leaving $10-\mathrm{mm}$ petiole stubs on the stems to foster the establishment of the pathogen, and $10-\mu l$ aliquots of spore suspension were applied to each pruning wound. Wounded petioles of leaves 5 and 7 were inoculated with strain $\mathrm{BC} 1$ and those from leaves 6 and 8 with strain BC21.

Disease assessment. All plants were incubated in a growth chamber with a 16 -h $\left(162 \mu \mathrm{mol} \mathrm{m} \mathrm{m}^{-2} \mathrm{~s}^{-1}\right)$ photoperiod at $21^{\circ} \mathrm{C}$ and relative humidity $>90 \%$. During this period, plants were watered once a day. The initiation and length of the resulting stem lesions was monitored daily for 7 days after inoculation. The area under 
the disease progress curve (AUDPC) was computed as described by Lecompte et al. (31) during the period from the third to the seventh day after inoculation and used for statistical analyses. The pathogenicity assessment experiment was repeated twice.

Data analysis. Statistical analyses were carried out using Statistica software (Statsoft Inc., Tulsa, OK). The ANOVA/MANOVA module was used for analyses of variance (ANOVAs) and for multiple comparisons of means (tests of Neuman and Keuls). A "trial effect" was tested because all experiments were carried out twice independently. No significant effect was detected and the data were pooled for further statistical analyses. Data on spore production were log-transformed prior to the analyses to stabilize the variance (57). Correlation analyses were carried out with the multiple regression module.

\section{RESULTS}

Influence of plant nutrition on spore production by $B$. cinerea on diseased leaves and stems. Both strains of $B$. cinerea included in this study sporulated abundantly on the two types of plant tissue tested (Fig. 1). Despite their known difference in aggressiveness on tomato (31), their level of spore production (expressed as number of spores per gram of fresh tissue 10 days after inoculation) did not differ significantly $(P=0.36)$. Sporulation of both strains was significantly affected by the type of plant tissue colonized $(P<0.001)$, being greater on leaf disks

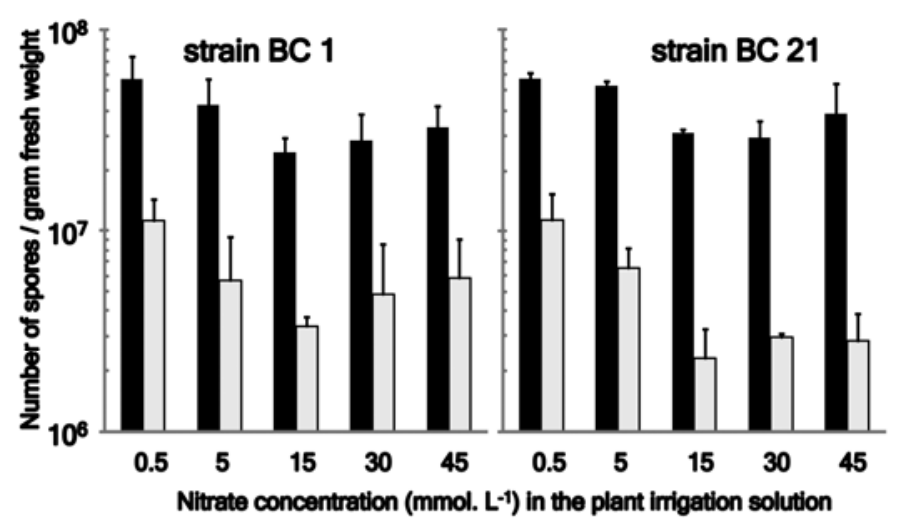

Fig. 1. Effect of $\mathrm{N}$ nutrition on sporulation of two strains of Botrytis cinerea on leaf disks (black bars) and stem segments (gray bars). Data represent the average number of spores produced in 10 days per gram of fresh tissue. Bars indicate the standard error of the mean (two independent tests $\times$ five replicates per test). than on stem segments. Spore production was also significantly affected $(P<0.001)$ on both plant tissues by the level of $\mathrm{N}$ fertilization provided to the tomato plants during their growth prior to inoculation. For both strains, spore production globally decreased with increasing plant $\mathrm{N}$ fertilization levels up to 15 to $30 \mathrm{mM}$ (Fig. 1).

Influence of plant nutrition on the weight and composition of leaf and stem tissues. The fresh and dry weight of both leaves and stems was significantly increased $(P<0.001$ in both cases) by $\mathrm{N}$ fertilization up to $15 \mathrm{mM}$ nitrate and then tended to decrease at higher $\mathrm{N}$ rates (Table 1). Leaf content of $\mathrm{N}, \mathrm{C}, \mathrm{P}$, and $\mathrm{Mg}$ was greater than that in stems but leaves were lower in $\mathrm{NO}_{3}{ }^{-}, \mathrm{K}$, and the three sugars (Table 1 ). $\mathrm{N}$ fertilization had a very significant effect $(P<0.001)$ on leaf tissue concentration of all measured components, whereas no significant effect was observed for $\mathrm{P}, \mathrm{K}$, $\mathrm{Mg}$, and $\mathrm{Ca}$ in stem tissue. The total $\mathrm{N}$ and $\mathrm{NO}_{3}{ }^{-}$content of stems and leaves increased with increasing $\mathrm{N}$ fertilization. $\mathrm{C}, \mathrm{P}, \mathrm{K}$, glucose, and fructose also tended to increase in leaves but $\mathrm{Mg}$ and Ca tended to decrease (Table 1).

Many of the plant components measured were significantly correlated (Supplemental Tables 1 and 2). The most highly correlated components in both plant organs were glucose with fructose ( $r=0.97$ in leaves and 0.83 in stems; $P<0.0001$ ), total $\mathrm{N}$ with $\mathrm{NO}_{3}^{-}(r=0.93$ in leaves and 0.97 in stems; $P<0.0001)$, and either of the two above sugars with total $\mathrm{N}$ or $\mathrm{NO}_{3}^{-}(r=0.82$ to 0.92 in leaves and 0.47 to 0.82 in stems; $P<0.0001$ ). A strong negative correlation was found between these four components and $\mathrm{Ca}$ in leaves $(r$ from -0.84 to $-0.92 ; P<0.0001$ ) but not in stems. A strong negative correlation was also found between sucrose and total $\mathrm{N}$ and $\mathrm{NO}_{3}^{-}(r=-0.76$ and -0.73 , respectively; $P<0.0001)$ in stems but not in leaves.

Relationship between tissue content and spore production. Significant correlations $(P<0.05)$ were observed between spore production by $B$. cinerea on detached organs of tomato plants and some of the tissue contents (Table 2). The only significant positive correlations were found between $\mathrm{Ca}$ content and sporulation on leaf disks $(r=0.96)$ and between sucrose and sporulation on stem segments $(r=0.94)$. Significant negative correlations ( $r$ values between -0.89 and -0.92 ) were found between sporulation on leaf disks and several mineral elements as well as glucose, fructose, and total sugars. In contrast, fructose and total sugars were the only components having a significant negative correlation $(r=$ -0.99 and -0.91 , respectively) with sporulation on stem segments.

Influence of plant nutrition on the pathogenicity of secondary inoculum. Initiation of stem cankers. Regardless of the inoculation point, Botrytis spp. colonized the short petiole stub and cankers eventually developed on the stems. The fertilization

TABLE 1. Effect of $\mathrm{N}$ fertilization on the fresh weight, dry matter, and tissue content of tomato leaves and stems

\begin{tabular}{|c|c|c|c|c|c|c|c|c|c|c|c|c|}
\hline \multirow[b]{2}{*}{ Fert. $(\mathrm{mM})^{\mathrm{y}}$} & \multicolumn{2}{|c|}{ Weight (g) } & \multicolumn{10}{|c|}{ Tissue content $(\mathrm{mg} / \mathrm{g} \text { of dry matter })^{\mathrm{z}}$} \\
\hline & Fresh & Dry & $\mathrm{N}$ & $\mathrm{NO}_{3}^{-}$ & $\mathrm{C}$ & $\mathrm{P}$ & $\mathrm{K}$ & $\mathrm{Mg}$ & $\mathrm{Ca}$ & Sucrose & Glucose & Fructose \\
\hline \multicolumn{13}{|l|}{ Leaves } \\
\hline 0.5 & $12.7 \mathrm{a}$ & $2.1 \mathrm{a}$ & $16.8 \mathrm{a}$ & $0.2 \mathrm{a}$ & $371.2 \mathrm{a}$ & $6.1 \mathrm{a}$ & $21.0 \mathrm{a}$ & $5.8 \mathrm{c}$ & $13.2 \mathrm{~d}$ & $6.6 \mathrm{a}$ & $3.9 \mathrm{a}$ & $4.8 \mathrm{a}$ \\
\hline 5 & $49.1 \mathrm{~b}$ & $6.4 \mathrm{~b}$ & $36.7 \mathrm{~b}$ & $0.5 \mathrm{a}$ & $394.3 \mathrm{~b}$ & $6.8 \mathrm{~b}$ & $27.5 \mathrm{~b}$ & $4.7 \mathrm{~b}$ & $10.2 \mathrm{c}$ & $9.3 \mathrm{~b}$ & $10.4 \mathrm{~b}$ & $9.6 \mathrm{~b}$ \\
\hline 15 & $96.0 \mathrm{~d}$ & $9.3 \mathrm{~d}$ & $59.9 \mathrm{c}$ & $16.6 \mathrm{~b}$ & $402.6 \mathrm{c}$ & $7.6 \mathrm{c}$ & $35.0 \mathrm{c}$ & $4.6 \mathrm{~b}$ & $7.5 \mathrm{~b}$ & $9.3 \mathrm{~b}$ & $15.3 \mathrm{c}$ & $14.3 \mathrm{c}$ \\
\hline 30 & $86.9 \mathrm{~d}$ & $8.5 \mathrm{~cd}$ & $66.1 \mathrm{~d}$ & $16.6 \mathrm{~b}$ & $414.5 \mathrm{~d}$ & $8.6 \mathrm{~d}$ & $29.7 \mathrm{~b}$ & $2.7 \mathrm{a}$ & $5.6 \mathrm{a}$ & $9.0 \mathrm{~b}$ & $21.6 \mathrm{~d}$ & $20.7 \mathrm{e}$ \\
\hline 45 & $73.9 \mathrm{c}$ & $7.4 \mathrm{bc}$ & $72.6 \mathrm{e}$ & $17.6 \mathrm{~b}$ & $423.3 \mathrm{e}$ & $8.5 \mathrm{~d}$ & $23.8 \mathrm{a}$ & $2.4 \mathrm{a}$ & $7.4 \mathrm{~b}$ & $7.2 \mathrm{a}$ & $17.2 \mathrm{c}$ & $17.8 \mathrm{~d}$ \\
\hline$P$ & $<0.001$ & $<0.001$ & $<0.001$ & $<0.001$ & $<0.001$ & $<0.001$ & $<0.001$ & $<0.001$ & $<0.001$ & $<0.001$ & $<0.001$ & $<0.001$ \\
\hline \multicolumn{13}{|l|}{ Stems } \\
\hline 0.5 & $8.4 \mathrm{a}$ & $1.0 \mathrm{a}$ & $9.1 \mathrm{a}$ & $0.1 \mathrm{a}$ & $338.5 \mathrm{~b}$ & 5.8 & 55.1 & 2.5 & 6.7 & $24.5 \mathrm{~b}$ & $71.3 \mathrm{a}$ & $9.6 \mathrm{a}$ \\
\hline 5 & $31.0 \mathrm{~b}$ & $2.6 \mathrm{~b}$ & $19.1 \mathrm{~b}$ & $2.0 \mathrm{a}$ & $327.1 \mathrm{a}$ & 4.9 & 44.6 & 2.0 & 5.3 & $18.0 \mathrm{a}$ & $127.1 \mathrm{c}$ & $27.4 \mathrm{~b}$ \\
\hline 15 & $55.1 \mathrm{~d}$ & $3.7 \mathrm{~d}$ & $37.5 \mathrm{c}$ & $41.0 \mathrm{~b}$ & $322.7 \mathrm{a}$ & 5.9 & 53.3 & 2.3 & 4.7 & $14.3 \mathrm{a}$ & $114.3 \mathrm{~b}$ & $38.3 \mathrm{c}$ \\
\hline 30 & $51.1 \mathrm{~d}$ & $3.8 \mathrm{~d}$ & $48.6 \mathrm{~d}$ & $48.6 \mathrm{c}$ & $338.8 \mathrm{~b}$ & 5.4 & 51.5 & 1.9 & 6.2 & $13.2 \mathrm{a}$ & $125.0 \mathrm{bc}$ & $36.1 \mathrm{c}$ \\
\hline 45 & $40.1 \mathrm{c}$ & $3.1 \mathrm{c}$ & $50.6 \mathrm{~d}$ & $55.8 \mathrm{~d}$ & $334.6 \mathrm{~b}$ & 8.3 & 49.1 & 2.1 & 8.6 & $11.8 \mathrm{a}$ & $121.3 \mathrm{bc}$ & $36.7 \mathrm{c}$ \\
\hline$P$ & $<0.001$ & $<0.001$ & $<0.001$ & $<0.001$ & $<0.001$ & $=0.80$ & $=0.81$ & $=0.59$ & $=0.343$ & $<0.001$ & $<0.001$ & $<0.001$ \\
\hline
\end{tabular}

y Nitrate fertilization level (mmole liter $\left.{ }^{-1}\right)$.

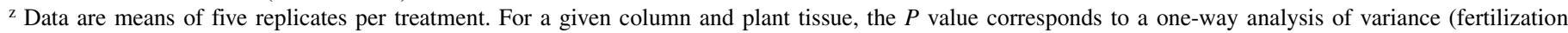
effect) and numbers followed by different letters are significantly different (Newman-Keuls tests; $P=0.05$ ). 
level of the plants and the type of organ used to produce secondary inoculum had little influence on the time needed to initiate stem cankers (latency period). Differences among treatments were not substantial, with a maximum of 0.5 day between the longest and the shortest latency period (Table 3); and ANOVA showed a significant $\mathrm{N}$ effect only for strain $\mathrm{BC} 1$ produced on stem segments $(P=0.015)$. Regardless of spore production substrate, the latency period was significantly longer $(P<0.001)$ for the mildly aggressive $\mathrm{BC} 21$ strain than for the highly aggressive $\mathrm{BC} 1$ strain.

Development of stem cankers. Canker development (AUDPC) was highly affected by the level of $\mathrm{N}$ fertilization provided to plants that were used as substrates for the production of inoculum (Fig. 2). The effect of $\mathrm{N}$ was more pronounced for the moreaggressive strain $\mathrm{BC} 1(P<0.001)$ than for the less-aggressive strain BC21 $(P<0.05)$. Interestingly, stem cankers were almost always longer for inoculum produced on PDA than for secondary inoculum produced on plant tissue (Fig. 2). The severity of lesions (AUDPC) was also significantly affected by the type of plant organ (leaf disk versus stem segment) used as substrate for spore production $(P<0.05)$. To facilitate the comparison of the effect of plant $\mathrm{N}$ fertilization on the pathogenicity of secondary inoculum for both strains of $B$. cinerea from both types of plant substrates relative to inoculum produced on PDA, an index of relative pathogenicity $(\mathrm{RP})$ was computed as the ratio $\mathrm{RP}=100 \times$ $\left(\mathrm{AUDPC}_{\text {plant substrate }} / \mathrm{AUDPC}_{\mathrm{PDA}}\right)$, where $\mathrm{AUDPC}_{\text {plant substrate }}$ is the severity of symptoms caused by inoculum produced on a given plant substrate and $\mathrm{AUDPC}_{\mathrm{PDA}}$ the severity of symptoms caused by inoculum produced on PDA medium. The relative pathogenicity of strain $\mathrm{BC} 1$ inoculum produced on stem segments was generally greater than that of inoculum produced on leaf disks (Fig. 3 ). No significant differences were observed for strain BC21. For

TABLE 2. Correlation between tissue content and spore production by Botrytis cinerea on leaf disks and stem segments

\begin{tabular}{lccccc}
\hline & \multicolumn{2}{c}{ Leaf disks } & & \multicolumn{2}{c}{ Stem segments } \\
\cline { 2 - 3 } \cline { 5 - 6 } Tissue content & $R^{\mathrm{y}}$ & $P$ value & & $R^{\mathrm{y}}$ & $P$ value \\
\hline $\mathrm{N}$ & -0.91 & 0.033 & & -0.83 & 0.080 \\
$\mathrm{NO}_{3}{ }^{-}$ & -0.92 & 0.025 & & -0.78 & 0.117 \\
$\mathrm{C}$ & -0.81 & 0.095 & & 0.47 & 0.418 \\
$\mathrm{P}$ & -0.87 & 0.056 & & -0.19 & 0.766 \\
$\mathrm{~K}$ & -0.78 & 0.123 & & 0.29 & 0.635 \\
$\mathrm{Mg}$ & 0.68 & 0.207 & & 0.59 & 0.298 \\
$\mathrm{Ca}$ & 0.96 & 0.011 & & 0.17 & 0.780 \\
$\mathrm{Sucrose}$ & -0.56 & 0.322 & & 0.94 & 0.019 \\
Glucose & -0.92 & 0.027 & & -0.85 & 0.065 \\
Fructose & -0.89 & 0.042 & & -0.99 & 0.001 \\
Total sugars & -0.92 & 0.026 & & -0.91 & 0.030 \\
\hline
\end{tabular}

y Correlation analyses were performed on pooled data from two independent sporulation tests, each with two strains of $B$. cinerea. Tissue content was expressed in milligrams per gram of dry matter and spore production was expressed as spore number per gram of fresh weight.

${ }^{\mathrm{z}}$ Sum of glucose, fructose, and sucrose.

TABLE 3. Effect of substrate used to produce inoculum of Botrytis cinerea on the time needed for symptom development (latency period in days) on the stems of tomato plants ${ }^{y}$

\begin{tabular}{lccccc}
\hline & \multicolumn{3}{c}{ BC1 } & & \multicolumn{2}{c}{ BC21 } \\
\cline { 2 - 3 } \cline { 5 - 6 } $\begin{array}{l}\text { Nitrate } \\
(\mathrm{mM})^{\mathrm{z}}\end{array}$ & $\begin{array}{c}\text { Leaf } \\
\text { disks }\end{array}$ & $\begin{array}{c}\text { Stem } \\
\text { segments }\end{array}$ & & $\begin{array}{c}\text { Leaf } \\
\text { disks }\end{array}$ & $\begin{array}{c}\text { Stem } \\
\text { segments }\end{array}$ \\
\hline 0.5 & $4.00 \pm 0.1$ & $3.53 \pm 0.1$ & & $4.19 \pm 0.1$ & $4.18 \pm 0.1$ \\
5 & $4.25 \pm 0.2$ & $4.06 \pm 0.3$ & & $4.28 \pm 0.0$ & $4.06 \pm 0.3$ \\
15 & $4.18 \pm 0.0$ & $3.81 \pm 0.1$ & & $4.00 \pm 0.0$ & $4.28 \pm 0.2$ \\
30 & $4.12 \pm 0.1$ & $3.62 \pm 0.2$ & & $4.14 \pm 0.2$ & $3.87 \pm 0.1$ \\
\hline
\end{tabular}

${ }^{\mathrm{y}}$ Inoculum was produced on either leaf disks or stem segments from plants subjected to four levels of $\mathrm{N}$ fertilization. Data are means of five replicates per treatment.

${ }^{\mathrm{z}}$ Nitrate fertilization $\left(\mathrm{mmol}\right.$ liter-1 $\left.^{-1}\right)$. both strains, the relative pathogenicity of secondary inoculum was highest when produced on organs from plants that received very low ( $0.5 \mathrm{mM}$ nitrate) or very high ( $30 \mathrm{mM}$ nitrate) levels of $\mathrm{N}$ fertilization (Fig. 3). Pathogenicity of inoculum was lowest from plants with moderate levels of $\mathrm{N}$.

Relationship between tissue constituents and pathogenicity of secondary inoculum. There was a significantly positive correlation $(P<0.05)$ of $\mathrm{C}$ content in the stems with pathogenicity of secondary inoculum $(r=0.98$ and 0.97 for strains $\mathrm{BC} 1$ and $\mathrm{BC} 21$, respectively) and a negative correlation with sucrose content in the leaves ( $r=-0.97$ for strain BC21) (Table 4). Correlations for other tissue constituents were not statistically significant $(P>$ $0.05)$.

\section{DISCUSSION}

This study showed that the level of $\mathrm{N}$ fertilization of tomato plants had a highly significant impact on the amount of spores produced by $B$. cinerea on diseased tissue as well as on the pathogenicity of this secondary inoculum. Sporulation was also

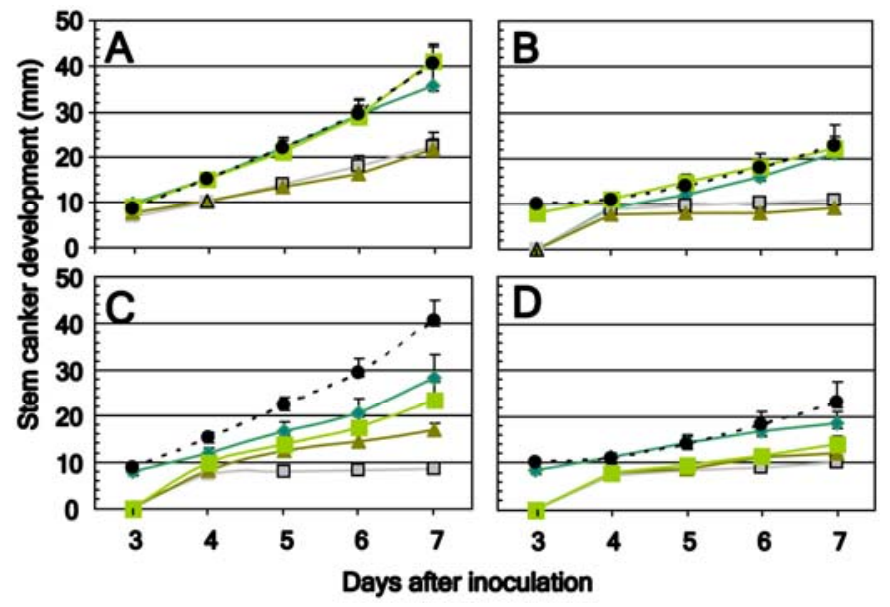

Fig. 2. Effect of substrate used to produce the inoculum of two strains of Botrytis cinerea $\mathbf{A}$ and $\mathbf{C}$, highly aggressive strain $\mathrm{BC} 1 ; \mathbf{B}$ and $\mathbf{D}$, mildly aggressive strain $\mathrm{BC} 21$ on the development of stem cankers on tomato 'Monalbo' plants. Inoculum was produced on A and B, stem segments or C and $\mathbf{D}$, leaf disks from plants subjected to four levels of nitrate fertilization (diamond, small square, triangle, and large square $=0.5,5,15$, and $30 \mathrm{mmol}$ $\operatorname{liter}^{-1}$, respectively). Inoculum produced on potato dextrose agar $(\bullet)$ was also tested for comparison. Bars represent the standard error of the means (two inoculation sites for each of five plants per treatment).

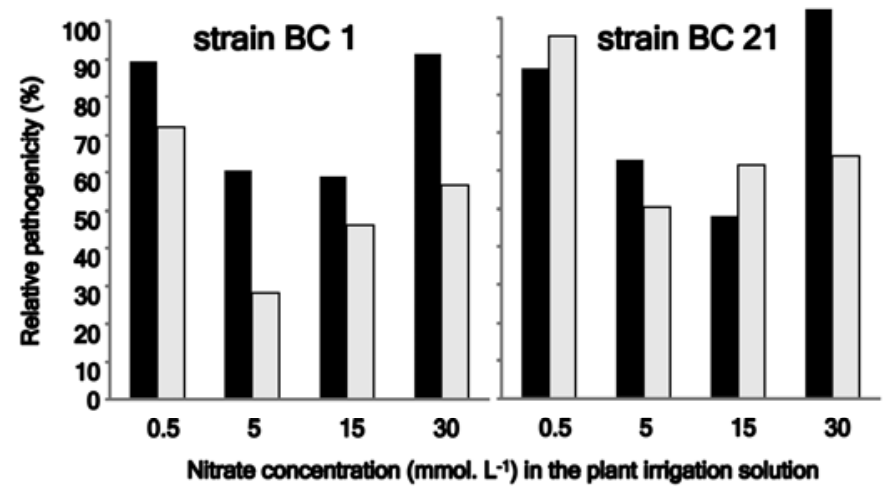

Fig. 3. Effect of $\mathrm{N}$ nutrition and plant tissue (stem segments [black bars] or leaf disks [gray bars]) on the pathogenicity of secondary inoculum of Botrytis cinerea to stems of tomato plants. Pathogenicity is expressed as the severity of disease (area under the disease progress curve) caused by secondary inoculum, relative to that of disease caused by inoculum produced on potato dextrose agar. 
affected by the type of plant tissue used as substrate. Although substrate composition has been reported to affect spore production by $B$. cinerea and other fungi $(7,16,32,35,54)$, few studies have addressed the effect of plant fertilization on the production of secondary inoculum on diseased tissue. Infection and spore production of Blumeria (syn. Erysiphe) graminis (powdery mildew of barley) was enhanced with increasing $\mathrm{N}$ fertilization $(3,25)$, as was spore production by Oidium neolycopersici on tomato leaves (21) and uredospore production per leaf lesion by Puccinia triticina on wheat (42). In contrast, our study of Botrytis cinerea on tomato shows that spore production was generally highest with low $\mathrm{N}$ fertilization (Fig. 1). Overall, this supports the hypothesis that biotrophs (such as the rusts and powdery mildews) and necrotophs (such as $B$. cinerea) may be differentially affected by $\mathrm{N}$ fertilization $(21,49)$. However, the plant species might also influence this because increasing $\mathrm{N}$ from 1.8 to $28.8 \mathrm{mM}$ in the irrigation solution of basil plants increased the incidence of sporulation by $B$. cinerea on stem segments (from nearly zero to $>75 \%$ ) 3 days after inoculation (55). Different strains of a pathogen might also be differently affected, although this was not the case for the two strains of $B$. cinerea used in our study.

Tissue analyses suggested that differences in $\mathrm{N}$ fertilization treatments resulted in complex differences in the physiological status of the plants that significantly affected fungal development. As reported in other studies $(22,23,55)$, we also observed that, in addition to total $\mathrm{N}$ and nitrate, the tissue content of soluble sugars and several minerals was significantly affected by $\mathrm{N}$ fertilization. Earlier work on tomato reported a positive correlation between the concentration of total soluble carbohydrates in leaves and the susceptibility of tomato plants to B. cinerea (22). Effects of plant tissue composition on spore production may be more complex because the correlations observed for $B$. cinerea in our study varied depending both on the type of plant tissue and on the type of sugar or mineral (Table 2). For example, total soluble sugars (glucose + fructose + sucrose) in our study were negatively correlated with spore production on both leaf disks and stem segments in contrast to plant susceptibility studied by Hoffland et al. (22). Furthermore, sucrose concentration was positively correlated with spore production on stem segments but negatively (not significant) correlated on leaf disks whereas glucose was negatively correlated for both types of plant tissues.

Thus, further studies are required to understand the mechanisms involved at the level of gene expression. Expression of the sporulation-regulating brlA gene of Aspergillus nidulans was reported to be induced by either glucose or $\mathrm{N}$ starvation but with different kinetics and with differing phenotypical outcomes (46). Similar studies with $B$. cinerea would be possible, because ortho- logs of genes known to function upstream of blrA (including $f a d \mathrm{~A}, f l u \mathrm{G}, f l b \mathrm{C}$, and $f l b \mathrm{D})$ have been reported in the genome of this fungus (1).

Trophic interactions related to primary metabolism are unlikely to be the only mechanisms implicated. Other compounds related to plant defense mechanisms were not examined in our study but would merit further attention because they could influence sporulation indirectly through their effect on plant tissue colonization by the pathogen. $\mathrm{N}$ nutrition has a large effect on the amino acid content (30) and constitutive phenolics (51) involved in various stages of the infection process in tomato. In other plant models, peroxidase and chitinase (two enzymes implicated in plant defense) were lower when $\mathrm{N}$ was limiting (11). Further work could also include the effect of $\mathrm{N}$ (and resulting differences in plant tissue constituents) on the expression of pathogenicityrelated genes of $B$. cinerea. N-limiting conditions can influence the expression of such genes for several plant-pathogenic fungi $(47,48)$ and possibly for human pathogens such as $A$. fumigatus (37).

Beyond an effect on sporulation, we also observed a highly significant effect of $\mathrm{N}$ fertilization and type of plant tissue on the pathogenicity of secondary inoculum produced on diseased tissue. Because the plants used for assessing pathogenicity were all produced under identical conditions and were inoculated with the same number of spores free of plant debris or maceration fluids from their initial production substrates, we hypothesize that the observed effects arose from actual differences in the spores themselves.

The effect of the growth medium on the composition of spores is well documented. Studies of the entomopathogenic fungi Beauveria bassiana, Metarhizium anisopliae, and Paecilomyees fumosoroseus showed that the composition of the growth medium influenced endogenous reserves of total carbohydrates, glycogen and lipids (29), trehalose and mannitol (39), erythritol (56), and proteins $(6,56)$ in spores. These effects were sometimes accompanied by differences in the behavior of the spores, notably their ability to survive various stress conditions and the kinetics of germination $(6,20,40,41)$. It would be interesting to analyze possible differences in various metabolites in $B$. cinerea spores affected by fertilization of the host plant. However, it is not clear whether a putative difference in the endogenous reserves of the secondary inoculum could account fully for the differences in pathogenicity observed in our study. At the early stage of infection, when endogenous reserves of the spores would likely have the most effect, only small and often nonstatistically significant differences were observed in the time needed for initiation of stem cankers (Table 3 ). In contrast, the subsequent phase of disease develop-

TABLE 4. Correlation between the pathogenicity of secondary inoculum of Botrytis cinerea on tomato plants and tissue content for various constituents of detached plant organs (leaf disks and stem segments) used to produce the spores

\begin{tabular}{|c|c|c|c|c|c|c|c|c|}
\hline \multirow[b]{3}{*}{ Content $^{\mathrm{x}}$} & \multicolumn{4}{|c|}{ Strain BC1 } & \multicolumn{4}{|c|}{ Strain BC21 } \\
\hline & \multicolumn{2}{|c|}{ Leaf disks } & \multicolumn{2}{|c|}{ Stem segments } & \multicolumn{2}{|c|}{ Leaf disks } & \multicolumn{2}{|c|}{ Stem segments } \\
\hline & $R^{\mathrm{y}}$ & $P$ value & $R^{\mathrm{y}}$ & $P$ value & $R^{\mathrm{y}}$ & $P$ value & $R^{\mathrm{y}}$ & $P$ value \\
\hline $\mathrm{NO}_{3}^{-}$ & 0.02 & 0.975 & 0.07 & 0.923 & -0.33 & 0.669 & 0.11 & 0.888 \\
\hline $\mathrm{C}$ & -0.40 & 0.592 & 0.98 & 0.018 & -0.73 & 0.262 & 0.96 & 0.032 \\
\hline $\mathrm{P}$ & -0.14 & 0.858 & 0.16 & 0.835 & -0.52 & 0.476 & -0.12 & 0.880 \\
\hline $\mathrm{K}$ & -0.50 & 0.499 & 0.49 & 0.501 & -0.70 & 0.295 & 0.23 & 0.768 \\
\hline Sucrose & -0.82 & 0.172 & 0.27 & 0.727 & -0.97 & 0.026 & 0.11 & 0.882 \\
\hline Glucose & -0.23 & 0.769 & -0.45 & 0.548 & -0.59 & 0.400 & -0.19 & 0.806 \\
\hline Fructose & -0.15 & 0.842 & -0.41 & 0.586 & -0.53 & 0.462 & -0.27 & 0.724 \\
\hline Total sugars ${ }^{\mathrm{z}}$ & -0.25 & 0.745 & -0.47 & 0.523 & -0.61 & 0.383 & -0.24 & 0.757 \\
\hline
\end{tabular}

$\mathrm{x}$ Tissue constituent.

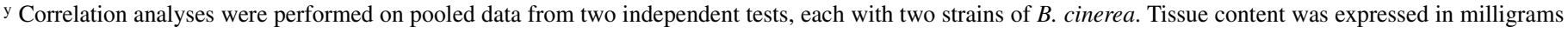
per gram of dry matter.

z Sum of glucose, fructose, and sucrose. 
ment and lesion expansion were strongly affected (Fig. 2), suggesting that the effect on the fungus long outlasted the possible mobilization of different endogenous reserves contained in the initial conidia. The implication of epigenetic phenomena reported for several other organisms subjected to different nutritional environments would merit more attention $(5,14,59)$.

In conclusion, the nutritional status of the host plant had a significant impact on the abundance and pathogenicity of secondary inoculum produced by plant-pathogenic $B$. cinerea. This information could lead to exciting new studies to elucidate cellular mechanisms involved and suggests that fertilization can influence the development of epidemics on a field scale. Conversely, it opens the possibility of manipulating crop fertilization not only to reduce plant susceptibility (31) but also to limit the impact of secondary inoculum and minimize the need for pesticide use.

\section{ACKNOWLEDGMENTS}

This work is part of the French 'Programme National de Recherches PIClèg' and the SYSBIOTEL program. It received financial support from INRA and the French 'Agence Nationale de la Recherche' (ANR). A grant for this study was also provided by the Higher Education Commission (HEC) of Pakistan. We thank F. de Bruyne, M. Duffaud, and M. Pascal for excellent technical assistance.

\section{LITERATURE CITED}

1. Amselem, J., Cuomo, C. A., van Kan, J. A. L., Viaud, M., Benito, E. P., Couloux, A., Coutinho, P. M., de Vries, R. P., Dyer, P. S., Fillinger, S., Fournier, E., Gout, L., Hahn, M., Kohn, L., Lapalu, N., Plummer, K. M., Pradier, J.-M., Eveline, Q., Sharon, A., Simon, A., ten Have, A., Tudzynski, B., Tudzynski, P., Wincker, P., Andrew, M., Veronique, A., Beever, R. E., Beffa, R., Benoit, I., Bouzid, O., Brault, B., Chen, Z., Choquer, M., Jerome, C., Cotton, P., Danchin, E. G., Da Silva, C., Angelique, G., Giraud, C., Giraud, T., Gonzalez, C., Grossetete, S., Ulrish, G., Henrissat, B., Howlett, B. J., Kodira, C., Kretschmer, M., Lappartient, A., Leroch, M., Levis, C., Mauceli, E., Cecile, N., Oeser, B., Pearson, M., Poulain, J., Poussereau, N., Quesneville, H., Rascle, C., Schumacher, J., Beatrice, S., Sexton, A., Silva, E., Sirven, C., Soanes, D. M., Talbot, N. J., Templeton, M., Yandava, C., Yarden, O., Zeng, Q., Rollins, J. A., Lebrun, M.-H., and Dickman, M. 2011. Genomic analysis of the necrotrophic fungal pathogens Sclerotinia sclerotiorum and Botrytis cinerea. PLOS Genet. 7(8):e1002230. Online publication. doi:10.1371/ journal.pgen.1002230

2. Arora, D. K., Filonow, A. B., and Lockwood, J. L. 1985. Decreased aggressiveness of Bipolaris-sorokiniana conidia in response to nutrient stress. Physiol. Plant Pathol. 26:135-142.

3. Bainbridge, A. 1974. Effect of nitrogen nutrition of the host on barley powdery mildew. Plant Pathol. 23:160-161.

4. Bena-Molaei, P., Talaei-Hassanloui, R., and Askary, H. 2011. Effect of culture substrates on virulence of Beauveria bassiana (Ascomycota: Cordycipitaceae) conidia against the brown tail moth, Euproctis chrysorrhoea (Lepidoptera: Lymantriidae). Biocontrol Sci. Technol. 21:619-624.

5. Burdge, G. C., Hanson, M. A., Slater-Jefferies, J. L., and Lillycrop, K. A. 2007. Epigenetic regulation of transcription: a mechanism for inducing variations in phenotype (fetal programming) by differences in nutrition during early life? Br. J. Nutr. 97:1036-1046.

6. Cliquet, S., and Jackson, M. A. 2005. Impact of carbon and nitrogen nutrition on the quality, yield and composition of blastospores of the bioinsecticidal fungus Paecilomyees fumosoroseus. J. Ind. Microbiol. Biotechnol. 32:204-210.

7. Dallemole-Giaretta, R., de Freitas, L. G., Caixeta, L. d. B., Xavier, D. M., Ferraz, S., and Silva Fabry, C. d. F. 2011. Production of chlamydospores of Pochonia chlamydosporia in different substrates. Cien. Agrotecnol. 35:314-321.

8. Decognet, V., Bardin, M., Trottin-Caudal, Y., and Nicot, P. C. 2009. Rapid change in the genetic diversity of Botrytis cinerea populations after the introduction of strains in a tomato glasshouse. Phytopathology 99:185-193.

9. De la Torre, M., and Cárdenas-Cota, H. 1996. Production of Paecilomyces Fumosoroseus conidia in submerged culture. Biocontrol 41:443-453.

10. De Vallavieille-Pope, C., Giosue, S., Munk, L., Newton, A. C., Niks, R. E., Ostergard, H., Pons-Kuhnemann, J., Rossi, V., and Sache, I. 2000. Assessment of epidemiological parameters and their use in epidemiological and forecasting models of cereal airborne diseases. Agronomie 20:715-727.
11. Dietrich, R., Ploss, K., and Heil, M. 2004. Constitutive and induced resistance to pathogens in Arabidopsis thaliana depends on nitrogen supply. Plant. Cell Environ. 27:896-906.

12. Divon, H. H., and Fluhr, R. 2007. Nutrition acquisition strategies during fungal infection of plants. FEMS Microbiol. Lett. 266:65-74.

13. Elad, Y., Williamson, B., Tudzynski, P., and Delen, N. 2004. Botrytis spp. and diseases they cause in agricultural systems - an introduction. Pages 124 in: Botrytis: Biology, Pathology and Control. Y. Elad, B. Williamson, P. Tudzynski, and N. Delen, eds. Kluwer Academic Publishers, Dordrecht, The Netherlands.

14. Feil, R. 2006. Environmental and nutritional effects on the epigenetic regulation of genes. Mutat. Res./Fundam. Mol. Mech. Mutag. 600:46-57.

15. Gao, L. 2011. Optimize culture conditions for biomass and sporulation of the nematophagous fungus Pochonia chlamydosporia, isolate HSY-12-14 by "two-step" cultivation. Afr. J. Microbiol. Res. 5:4731-4738.

16. Gao, L., and Liu, X. 2010. Effects of carbon concentrations and carbon to nitrogen ratios on sporulation of two biological control fungi as determined by different culture methods. Mycopathologia 169:475-481.

17. Gao, L., Sun, M. H., Liu, X. Z., and Che, Y. S. 2007. Effects of carbon concentration and carbon to nitrogen ratio on the growth and sporulation of several biocontrol fungi. Mycol. Res. 111:87-92.

18. Gomez, L., Bancel, D., Rubio, E., and Vercambre, G. 2007. The microplate reader: an efficient tool for the separate enzymatic analysis of sugars in plant tissues-validation of a micro-method. J. Sci. Food Agric. 87:1893-1905.

19. Hallsworth, J. E., and Magan, N. 1994. Effect of carbohydrate type and concentration on polyhydroxy alcohol and trehalose content of conidia of 3 entomopathogenic fungi. Microbiology 140:2705-2713.

20. Hallsworth, J. E., and Magan, N. 1995. Manipulation of intercellular glycerol and erythritol enhances germination of conidia at lower water availability. Microbiology 141:1109-1115.

21. Hoffland, E., Jeger, M. J., and van Beusichem, M. L. 2000. Effect of nitrogen supply rate on disease resistance in tomato depends on the pathogen. Plant Soil 218:239-247.

22. Hoffland, E., van Beusichem, M. L., and Jeger, M. J. 1999. Nitrogen availability and susceptibility of tomato leaves to Botrytis cinerea. Plant Soil 210:263-272.

23. Huber, D. M. 1980. The role of mineral nutrition in defense. Pages 381406 in: Plant Disease. An Advanced Treatise. Vol. V. How Plants Defend Themselves. J. G. Horsfall and E. B. Cowling, eds. Academic Press, New York.

24. Ibrahim, L., Butt, T. M., and Jenkinson, P. 2002. Effect of artificial culture media on germination, growth, virulence and surface properties of the entomopathogenic hyphomycete Metarhizium anisopliae. Mycol. Res. 106:705-715.

25. Jensen, B., and Munk, L. 1997. Nitrogen-induced changes in colony density and spore production of Erysiphe graminis f. sp. hordei on seedlings of six spring barley cultivars. Plant Pathol. 46:191-202.

26. Kassa, A., Brownbridge, M., Parker, B. L., Skinner, M., Gouli, V., Gouli, S., Guo, M., Lee, F., and Hata, T. 2008. Whey for mass production of Beauveria bassiana and Metarhizium anisopliae. Mycol. Res. 112:583591.

27. Köhl, J., Molhoek, W. L., van der Plas, C. H., and Fokkema, N. J. 1995. Suppression of sporulation of Botrytis spp. as a valid biocontrol strategy. Eur. J. Plant Pathol. 101:251-259.

28. Krauss, S., Schnitzler, W. H., Grassmann, J., and Woitke, M. 2005. The Influence of different electrical conductivity values in a simplified recirculation soilless system on inner and outer fruit quality characteristics of tomato. J. Agric. Food. Chem. 54:441-448.

29. Lane, B. S., Trinci, A. P. J., and Gillespie, A. T. 1991. Endogenous reserves and survival of blastospores of Beauveria-bassiana harvested from carbon-limited and nitrogen-limited batch cultures. Mycol. Res. 95:821-828.

30. Le Bot, J., Jeannequin, B., and Fabre, R. 2001. Impacts of N-deprivation on the yield and nitrogen budget of rockwool grown tomatoes. Agronomie 21:341-350.

31. Lecompte, F., Abro, M. A., and Nicot, P. C. 2010. Contrasted responses of Botrytis cinerea isolates developing on tomato plants grown under different nitrogen nutrition regimes. Plant Pathol. 59:891-899.

32. Maas, J. L., and Powelson, R. L. 1972. Growth and sporulation of Botrytis convoluta with various carbon and nitrogen sources. Mycologia 64:897-903.

33. Meredith, D. S. 1973. Significance of spore release and dispersal mechanisms in plant disease epidemiology. Annu. Rev. Phytopathol. 11:313342 .

34. Mustafa, U., and Kaur, G. 2009. Effects of carbon and nitrogen sources and ratio on the germination, growth and sporulation characteristics of Metarhizium anisopliae and Beauveria bassiana isolates. Afr. J. Agric. Res. 4:922-930.

35. Nicot, P. C., Mermier, M., Vaissiere, B. E., and Lagier, J. 1996. Differential spore production by Botrytis cinerea on agar medium and plant 
tissue under near-ultraviolet light-absorbing polyethylene film. Plant Dis. 80:555-558.

36. Oneill, T. M., Shtienberg, D., and Elad, Y. 1997. Effect of some host and microclimate factors on infection of tomato stems by Botrytis cinerea. Plant Dis. 81:36-40.

37. Panepinto, J. C., Oliver, B. G., Amlung, T. W., Askew, D. S., and Rhodes, J. C. 2002. Expression of the Aspergillus fumigatus rhe b homologue, rhbA, is induced by nitrogen starvation. Fungal Genet. Biol. 36:207-214.

38. Phillips, D. J., Margosan, D. A., and Mackey, B. E. 1987. Size, nuclear number, and aggressiveness of Botrytis cinerea spore produced on media of varied glucose concentrations. Phytopathology 77:1606-1608.

39. Rangel, D. E. 2008. Stress induced cross-protection against environmental challenges on prokaryotic and eukaryotic microbes. World J. Microbiol. Biotechnol. 27:1281-1296.

40. Rangel, D. E., Alston, D. G., and Roberts, D. W. 2008. Effects of physical and nutritional stress conditions during mycelial growth on conidial germination speed, adhesion to host cuticle, and virulence of Metarhizium anisopliae, an entomopathogenic fungus. Mycol. Res. 112:1355-1361.

41. Rangel, D. E., Anderson, A. J., and Roberts, D. W. 2008. Evaluating physical and nutritional stress during mycelial growth as inducers of tolerance to heat and UV-B radiation in Metarhizium anisopliae conidia. Mycol. Res. 112:1362-1372.

42. Robert, C., Bancal, M. O., and Lannou, C. 2004. Wheat leaf rust uredospore production on adult plants: Influence of leaf nitrogen content and Septoria tritici blotch. Phytopathology 94:712-721.

43. Schisler, D. A., Jackson, M. A., and Bothast, R. J. 1991. Influence of nutrition during conidiation of Colletotrichum truncatum on conidial germination and efficacy in inciting disease in Sesbania exaltata. Phytopathology 81:458-461.

44. Shah, F. A., Wang, C. S., and Butt, T. M. 2005. Nutrition influences growth and virulence of the insect-pathogenic fungus Metarhizium anisopliae. FEMS Microbiol. Lett. 251:259-266.

45. Shtienberg, D., Elad, Y., Niv, A., Nitzani, Y., and Kirshner, B. 1998. Significance of leaf infection by Botrytis cinerea in stem rotting of tomatoes grown in non-heated greenhouses. Eur. J. Plant Pathol. 104:753763.

46. Skromne, I., Sanchez, O., and Aguirre, J. 1995. Starvation stress modulates the expression of the Aspergillus nidulans brlA regulatory gene. Microbiology 141:21-28.

47. Snoeijers, S. S., Perez-Garcia, A., Joosten, M., and De Wit, P. 2000. The effect of nitrogen on disease development and gene expression in bacterial and fungal plant pathogens. Eur. J. Plant Pathol. 106:493-506.

48. Solomon, P. S., Nielsen, P. S., Clark, A. J., and Oliver, R. P. 2000. Methionine synthase, a gene required for methionine synthesis, is expressed in planta by Cladosporium fulvum. Mol. Plant Pathol. 1:315-323.

49. Solomon, P. S., Tan, K. C., and Oliver, R. P. 2003. The nutrient supply of pathogenic fungi; a fertile field for study. Mol. Plant Pathol. 4:203-210.

50. Steyaert, J. M., Weld, R. J., and Stewart, A. 2010. Isolate-specific conidiation in Trichoderma in response to different nitrogen sources. Fungal Biol.. 114:179-188.

51. Stout, M. J., Brovont, R. A., and Duffey, S. S. 1998. Effect of nitrogen availability on expression of constitutive and inducible chemical defenses in tomato, Lycopersicon esculentum. J. Chem. Ecol. 24:945-963.

52. Verhoeff, K. 1968. Studies on Botrytis cinerea in tomatoes. Effect of soil nitrogen level and of methods of deleafing upon the occurrence of $B$. cinerea under commercial conditions. Eur. J. Plant Pathol. 74:184-192.

53. Williamson, B., Tudzynski, B., Tudzynski, P., and van Kan, J. 2007. Botrytis cinerea: the cause of grey mould disease. Mol. Plant Pathol. 8:561-580.

54. Winder, R. S. 1999. The influence of substrate and temperature on the sporulation of Fusarium avenaceum and its virulence on marsh reed grass. Mycol. Res. 103:1145-1151.

55. Yermiyahu, U., Shamai, I., Peleg, R., Dudai, N., and Shtienberg, D. 2006. Reduction of Botrytis cinerea sporulation in sweet basil by altering the concentrations of nitrogen and calcium in the irrigation solution. Plant Pathol. 55:544-552.

56. Ypsilos, I. K., and Magan, N. 2005. Characterization of optimum cultural environmental conditions for the production of high numbers of Metarhizium anisopliae blastospores with enhanced ecological fitness. Biocontrol. Sci. Technol. 15:683-699.

57. Zar, J. H. 1984. Biostatistical Analysis. Prentice Hall, Englewood Cliffs, $\mathrm{NJ}$

58. Zarzycka, H. 1995. Effect of culturing Phytophthora infestans on various substrates on expression of its virulence and aggressiveness to potato. Phytopathol. Pol. 9(XXI):81-88.

59. Zeisel, S. H. 2009. Epigenetic mechanisms for nutrition determinants of later health outcomes. Am. J. Clin. Nutr. 89:S1488-S1493.

60. Zhao, S., and Shamoun, S. F. 2006. The effects of culture media, solid substrates, and relative humidity on growth, sporulation and conidial discharge of Valdensinia heterodoxa. Mycol. Res. 110:1340-1346. 